\title{
Reinekea aestuarii sp. nov., isolated from tidal flat sediment
}

\author{
Ahyoung Choi and Jang-Cheon Cho \\ Division of Biology and Ocean Sciences, Inha University, Incheon 402-751, Republic of Korea
}

Correspondence

Jang-Cheon Cho

chojc@inha.ac.kr

Two Gram-negative, non-motile, non-pigmented and curved rod-shaped bacterial strains, designated IMCC4489 ${ }^{\top}$ and IMCC4451, were isolated from a tidal flat sediment of the Yellow Sea. Strains IMCC $4489^{\top}$ and IMCC4451 shared $99.9 \% 16$ S rRNA gene sequence similarity and $78.5 \%$ DNA-DNA relatedness, which suggested that they belonged to the same species. The isolates were most closely related to Reinekea blandensis MED297 ${ }^{\top}$ (98.7-98.8\% 16S rRNA gene sequence similarity) and Reinekea marinisedimentorum DSM 15388 ${ }^{\top}$ (95.3-95.4\%). DNA-DNA relatedness between the strains and R. blandensis CCUG 52066 ${ }^{\top}$ was $31-34 \%$. Strains IMCC4489 ${ }^{\top}$ and IMCC4451 could also be differentiated from the type strains of the two recognized Reinekea species by several phenotypic properties. The DNA G + C content was 51.3-51.5 mol\% and the major isoprenoid quinone was Q-8. On the basis of the data obtained in this study, it is proposed that strains IMCC $4489^{\top}$ and IMCC4451 represent a novel species, Reinekea aestuarii sp. nov. The type strain is $\mathrm{IMCC}_{4} 489^{\top}\left(=\mathrm{KCTC} 22813^{\top}=\mathrm{KCCM} 42938^{\top}\right.$ $=$ NBRC $106079^{\top}$ ).

The genus Reinekea (Romanenko et al., 2004) in the order Oceanospirillales (Garrity et al., 2005) accommodates Gramnegative, chemoheterotrophic, aerobic or facultatively anaerobic, non-pigmented, motile, rod-shaped bacteria. At present, the genus Reinekea comprises two recognized species, Reinekea marinisedimentorum (Romanenko et al., 2004) and Reinekea blandensis (Pinhassi et al., 2007). R. marinisedimentorum is the type species of the genus, isolated from a coastal sediment sample, and R. blandensis MED $297^{\mathrm{T}}$ is a genome-sequenced bacterium, isolated from a seawater sample. Both species require sodium ions for growth. During a survey of microbial diversity inhabiting tidal flat sediments of the Yellow Sea, two bacterial strains, IMCC4489 ${ }^{\mathrm{T}}$ and IMCC4451, were isolated using a dilution-plating method and subjected to a taxonomic study. On the basis of the present taxonomic study, we propose the inclusion of these two strains in a novel species of the genus Reinekea.

Strains IMCC4489 ${ }^{\mathrm{T}}$ and IMCC4451 were isolated from a tidal flat sediment sample collected off the Yellow Sea coast (Kanghwa tidal flat, Korea; $37^{\circ} 36^{\prime} 07^{\prime \prime} \mathrm{N} 126^{\circ} 29^{\prime} 10^{\prime \prime} \mathrm{E}$; $\left.20^{\circ} \mathrm{C}\right)$. The sediment sample ( $1 \mathrm{~g}$ wet weight) was homogenized with a glass mixer in $100 \mathrm{ml}$ sterile seawater. A $100 \mu \mathrm{l}$ sample of the homogenate was spread onto an oligotrophic medium, 1/10 R2A agar [R2A agar (BD Difco)

The GenBank/EMBL/DDBJ accession numbers for the 16S rRNA gene sequences of strains IMCC4489 ${ }^{\top}$ and IMCC4451 are GQ456131 and G0280347, respectively.

A thin-layer chromatogram of the polar lipids of strain IMCC $4489^{\top}$ is available as supplementary material with the online version of this paper. diluted $1: 10(\mathrm{v} / \mathrm{v})$ with aged seawater] and the agar plates were incubated aerobically at $20{ }^{\circ} \mathrm{C}$ for 30 days. The nonpigmented colonies of the isolates were subcultivated on marine agar 2216 (MA; BD Difco) for 7 days. After the optimum temperature for growth had been determined, the strains were routinely grown on $\mathrm{MA}$ at $25^{\circ} \mathrm{C}$. For phenotypic, chemotaxonomic and genotypic comparisons between the isolates and the genus Reinekea, two reference type strains, R. marinisedimentorum DSM $15388^{\mathrm{T}}$ and $R$. blandensis CCUG $52066^{\mathrm{T}}$, were obtained from the DSMZ and the CCUG, respectively.

Genomic DNA was extracted from purified colonies using a DNeasy tissue kit (Qiagen), according to the manufacturer's instructions. DNA-DNA relatedness among the isolates and reference strains was determined by a fluorometric method (Ezaki et al., 1989) using photobiotin-labelled DNA probes and microdilution wells. The $16 \mathrm{~S}$ rRNA gene was amplified using the primers 27F-B and 1492R and sequenced as described by Cho \& Giovannoni (2004). The resultant almost-complete 16S rRNA gene sequences of strains IMCC4489 ${ }^{\mathrm{T}}$ and IMCC4451 (both $1466 \mathrm{bp}$ ) were imported into the ARB software package (Ludwig et al., 2004) and aligned on the basis of the secondary structure of the $16 \mathrm{~S}$ rRNA. Sequence similarities were determined in the ARB package and also confirmed by the EzTaxon server (Chun et al., 2007). Phylogenetic trees were generated using the neighbour-joining method (Saitou \& Nei, 1987) with Jukes-Cantor distances (Jukes \& Cantor, 1969) and the maximum-parsimony (Fitch, 1971) and maximum-likelihood (Felsenstein, 1981) methods. 
Strains IMCC4489 ${ }^{\mathrm{T}}$ and IMCC4451 shared 99.9\% 16S rRNA gene sequence similarity and exhibited $78.5 \%$ DNA-DNA relatedness, and thus they were considered to be members of the same genomic species (Wayne et al., 1987). On the basis of 16S rRNA gene sequence comparisons, the isolates were most closely related to R. blandensis MED297 ${ }^{\mathrm{T}}$ (98.7-98.8 \% 16S rRNA gene sequence similarity), $R$. marinisedimentorum DSM $15388^{\mathrm{T}}$ (95.3-95.4\%) and Saccharospirillum impatiens EL-105 ${ }^{\mathrm{T}}(93.7-93.8 \%)$. In all of the phylogenetic trees, strains IMCC4489 ${ }^{\mathrm{T}}$ and IMCC4451, R. marinisedimentorum DSM $15388^{\mathrm{T}}$ and $R$. blandensis MED297 ${ }^{\mathrm{T}}$ formed a wellsupported clade within the order Oceanospirillales (Fig. 1), indicating that strains IMCC $4489^{\mathrm{T}}$ and IMCC4451 were members of the genus Reinekea. DNA-DNA relatedness between the isolates and R. blandensis CCUG $52066^{\mathrm{T}}$ was 31$34 \%$. The values of $<97 \% 16 \mathrm{~S}$ rRNA gene sequence similarity between the isolates and $R$. marinisedimentorum DSM $15388^{\mathrm{T}}$ and $<70 \%$ DNA-DNA relatedness between the isolates and R. blandensis CCUG $52066^{\mathrm{T}}$ indicated that strains IMCC $4489^{\mathrm{T}}$ and IMCC4451 represented a genomic species separate from the two recognized Reinekea species (Wayne et al., 1987; Stackebrandt \& Goebel, 1994; Stackebrandt \& Ebers, 2006).

For phenotypic characterization, strains IMCC $4489^{\mathrm{T}}$ and IMCC4451 were grown on MA at $25{ }^{\circ} \mathrm{C}$ unless otherwise stated. Cellular morphology and cell size were examined by both transmission electron microscopy (CM200; Philips) and phase-contrast microscopy (80i; Nikon). Flagellumbased motility was determined using a wet mount made from fresh cultures grown in marine broth at $25{ }^{\circ} \mathrm{C}$ for $24 \mathrm{~h}$ and gliding motility was determined using the hanging-drop method. Growth of the strains under anaerobic conditions was tested in an Anaero Pack anaerobic chamber (Mitsubishi Gas Chemical) for 3 weeks. Conditions for growth were determined at $4,10,15,20,25$, 30,37 and $42{ }^{\circ} \mathrm{C}$, at $\mathrm{pH} 4.0-12.0$ (at intervals of $0.5 \mathrm{pH}$ units) and with $0-15 \%(\mathrm{w} / \mathrm{v}) \mathrm{NaCl}$ in $\mathrm{NaCl}$-free artificial seawater medium (ASW; Choo et al., 2007) amended with
$5.0 \mathrm{~g}$ peptone and $1.0 \mathrm{~g}$ yeast extract $\mathrm{l}^{-1}$. Catalase activity was determined with the addition of $3.0 \%$ hydrogen peroxide to fresh colonies and oxidase activity was determined using Kovács' solution. Hydrolysis of gelatin, casein, starch, DNA, chitin and Tween 80 , production of $\mathrm{H}_{2} \mathrm{~S}$ and the Voges-Proskauer test were determined according to the methods described by Smibert \& Krieg (1994) except for using MA as a basal medium. Other biochemical tests and carbon source oxidation tests were carried out for the isolates and reference strains using API 20NE, API ZYM and API 50CH test strips (bioMérieux) and GN2 MicroPlates (Biolog) according to the manufacturers' instructions except for suspending the cells in ASW medium. The API 50CH results were recorded after 3 days.

The phenotypic characteristics of strains $\mathrm{IMCC}_{4} 489^{\mathrm{T}}$ and IMCC4451 are given in the species description and Table 1. Briefly, cells of the isolates were Gram-negative (by Gram staining and $\mathrm{KOH}$ test), chemoheterotrophic, facultatively anaerobic, oxidase- and catalase-positive, non-motile, nonpigmented, curved rods that required $\mathrm{NaCl}$ for growth. Strains IMCC4489 ${ }^{\mathrm{T}}$ and IMCC4451 exhibited slightly different patterns of acid production from carbohydrates and carbon source oxidation. A number of phenotypic characteristics differentiated the isolates from one or both of the reference strains, including anaerobic growth, motility, nitrate reduction, enzyme activities and acid production and carbon source oxidation patterns (Table 1).

The DNA G $+\mathrm{C}$ content was determined using the HPLC method (Mesbah et al., 1989) with a Discovery C18 column $(5 \mu \mathrm{m}, 15 \mathrm{~cm} \times 4.6 \mathrm{~mm}$; Supelco). The fatty acid methyl esters of the isolates and the reference strains were extracted from fresh cultures grown on MA at $25{ }^{\circ} \mathrm{C}$ for 5 days and determined by the Sherlock Microbial Identification System (MIDI), according to the manufacturer's instructions. The polar lipids of strain IMCC $4489^{\mathrm{T}}$ were determined using two-dimensional TLC on silica gel according to Minnikin et al. (1984). Isoprenoid quinones

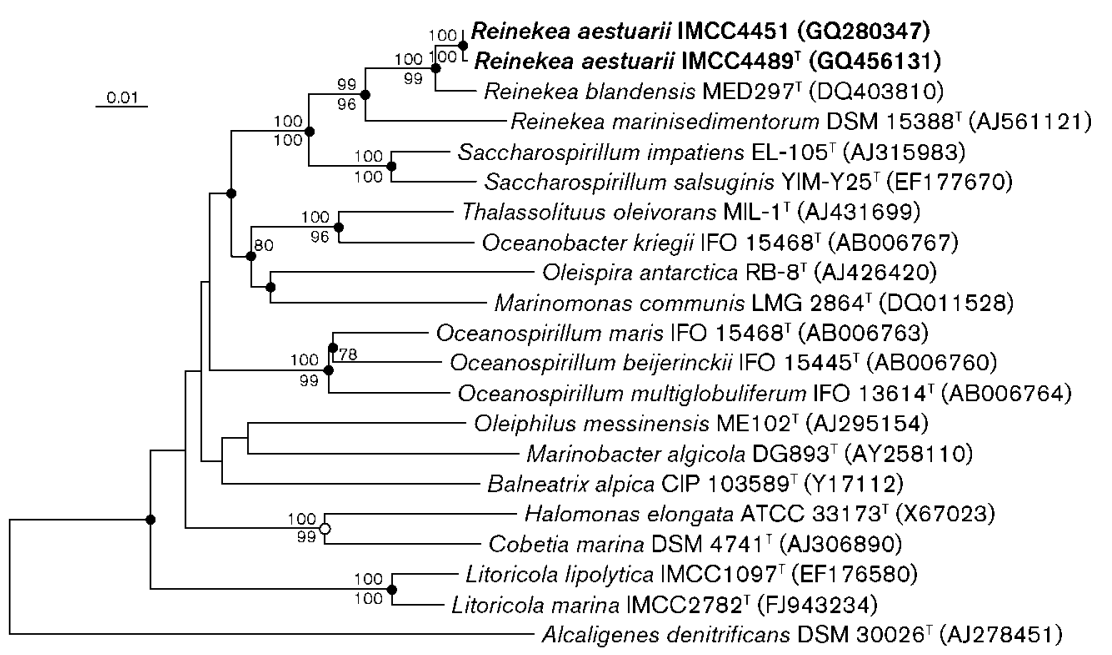

Fig. 1. Neighbour-joining phylogenetic tree, based on 16S rRNA gene sequences, showing the relationships between strains IMCC $4489^{\top}$ and IMCC4451 and their relatives in the order Oceanospirillales. Filled circles indicate that the corresponding nodes were also recovered in trees generated with the maximum-parsimony and maximum-likelihood methods. The open circle indicates that the corresponding node was also recovered in trees generated with the maximum-parsimony method. Bootstrap values $(>70 \%)$ are shown at branch nodes for the neighbour-joining and maximum-parsimony analysis (above and below nodes, respectively). Alcaligenes denitrificans JCM $5490^{\top}$ was used as an outgroup. Bar, 0.01 substitutions per nucleotide position. 


\section{Table 1. Characteristics that differentiate strains IMCC4489 ${ }^{\top}$ and IMCC4451 from the type strains of Reinekea species}

Strains: 1, Reinekea aestuarii sp. nov. IMCC4489 ${ }^{\mathrm{T}}$ and IMCC4451 (for variable characters, result given for IMCC4489 $/$ IMCC4451); 2, R. blandensis CCUG $52066^{\mathrm{T}} ; 3$, R. marinisedimentorum DSM $15388^{\mathrm{T}}$. Data were obtained in this study unless indicated. All strains were positive for aesculin hydrolysis, acid phosphatase, alkaline phosphatase, esterase (C4), esterase lipase (C8), leucine arylamidase, acid production from aesculin ferric citrate and oxidation of cellobiose, D-fructose, $\alpha$-D-glucose, maltose, D-mannitol, D-sorbitol, sucrose, trehalose and D-glucose 6-phosphate. All strains were negative for indole production, arginine dihydrolase, urease, $\alpha$-chymotrypsin, $\alpha$-fucosidase, $\beta$-glucuronidase, $\alpha$-mannosidase, acid production from D-arabinose, D- and L-fucose, D-lyxose, melezitose, L-rhamnose, D-ribose, L-sorbose, D-tagatose, D- and L-xylose, methyl $\alpha$-Dmannopyranoside, methyl $\beta$-D-xylopyranoside, D-adonitol, D- and L-arabitol, dulcitol, erythritol, inositol, D-sorbitol, xylitol, inulin, potassium gluconate and potassium 2-ketogluconate and oxidation of Tweens 40 and 80, L-arabinose, L-fucose, L-rhamnose, myo-inositol, xylitol, pyruvic acid methyl ester, succinic acid monomethyl ester, cis-aconitic acid, formic acid, D-galactonic acid lactone, D-gluconic acid, D-glucuronic acid, $\gamma$ hydroxybutyric acid, $p$-hydroxyphenylacetic acid, itaconic acid, $\alpha$-ketobutyric acid, $\alpha$-ketovaleric acid, malonic acid, propionic acid, quinic acid, Dsaccharic acid, sebacic acid, bromosuccinic acid, succinamic acid, glucuronamide, L-alanyl glycine, glycyl L-aspartic acid, L-histidine, hydroxy-Lproline, L-leucine, L-phenylalanine, L-pyroglutamic acid, D- and L-serine, L-threonine, DL-carnitine, urocanic acid, phenylethylamine, putrescine or 2,3-butanediol. +, Positive; w, weakly positive; -, negative.

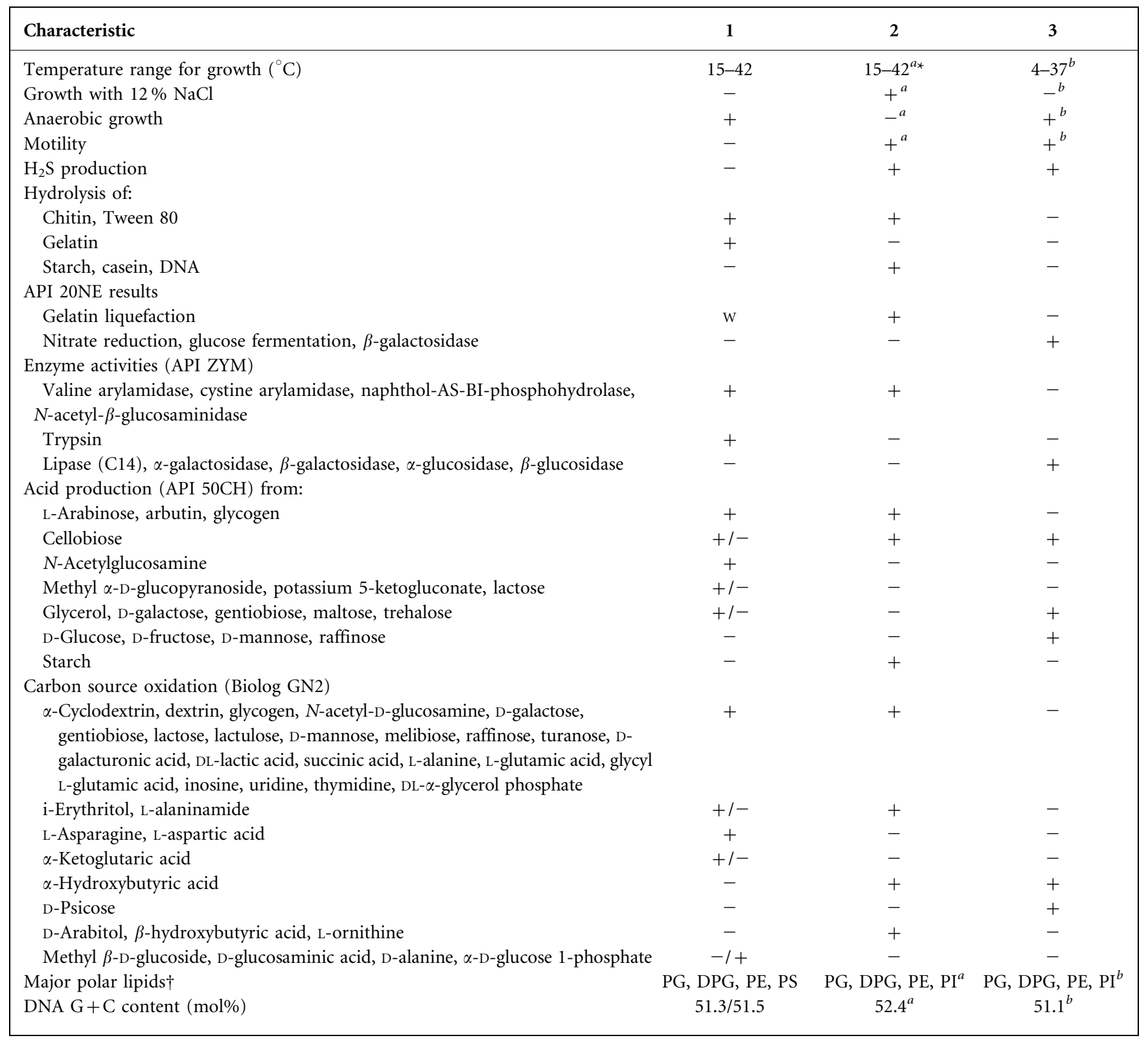

${ }^{\star}$ Data taken from: $a$, Pinhassi et al. (2007); b, Romanenko et al. (2004).

$\nmid$ DPG, Diphosphatidylglycerol; PE, phosphatidylethanolamine; PG, phosphatidylglycerol; PI, phosphatidylinositol; PS, phosphatidylserine. 
were extracted by TLC according to Minnikin et al. (1984) and analysed by using HPLC (Collins, 1985).

The DNA G+C contents of strains $\mathrm{IMCC}_{4} 489^{\mathrm{T}}$ and IMCC4451 were 51.3 and $51.5 \mathrm{~mol} \%$, respectively, only $0.2-1.1 \mathrm{~mol} \%$ different from those of $R$. blandensis CCUG $52066^{\mathrm{T}}$ and $R$. marinisedimentorum DSM $15388^{\mathrm{T}}$ (Table 1). The major cellular fatty acid components of strain IMCC $4489^{\mathrm{T}}$ were summed feature $8\left(\mathrm{C}_{18: 1} \omega 7 c\right.$ and/or $\left.\mathrm{C}_{18: 1} \omega 6 c ; 27.4 \%\right)$, iso- $\mathrm{C}_{16: 0}(16.7 \%)$, summed feature 3 $\left(\mathrm{C}_{16: 1} \omega 7 c\right.$ and/or $\left.\mathrm{C}_{16: 1} \omega 6 c ; 10.7 \%\right), \mathrm{C}_{16: 0} \quad(9.6 \%)$, $\mathrm{C}_{17: 1} \omega 8 c(6.8 \%)$ and iso- $\mathrm{C}_{18: 0}(5.5 \%)$. The fatty acid profiles of strains IMCC $4489^{\mathrm{T}}$ and IMCC4451 were largely similar to that of R. blandensis CCUG $52066^{\mathrm{T}}$ except for the proportions of $\mathrm{C}_{17: 1} \omega 6 c$ and iso- $\mathrm{C}_{16: 0}$, but they differed from that of $R$. marinisedimentorum DSM $15388^{\mathrm{T}}$ in the presence of iso- $C_{16: 0}$ and iso- $C_{18: 0}$ and in the proportions of $\mathrm{C}_{17: 0}$ and $\mathrm{C}_{17: 1} \omega 6 c$ (Table 2). The polar lipids of strain IMCC $4489^{\mathrm{T}}$ included diphosphatidylglycerol, phosphatidylglycerol, phosphatidylethanolamine, phosphatidylserine,

Table 2. Cellular fatty acid compositions of strains IMCC $4489^{\top}$ and IMCC4451 and type strains of the genus Reinekea

Strains: $1, R$. aestuarii sp. nov. IMCC $4489^{\mathrm{T}} ; 2, R$. aestuarii sp. nov. IMCC4451; 3, R. blandensis CCUG 52066 ${ }^{\mathrm{T}} ; 4, R$. marinisedimentorum DSM $15388^{\mathrm{T}}$. Values are percentages of total fatty acids and were obtained in this study. Fatty acids that represented $<1.0 \%$ in all strains are not shown. tr, Trace $(<1.0 \%) ;-$, not detected.

\begin{tabular}{|c|c|c|c|c|}
\hline Fatty acid & 1 & 2 & 3 & 4 \\
\hline $\mathrm{C}_{14: 0}$ & $\operatorname{tr}$ & $\operatorname{tr}$ & $\operatorname{tr}$ & 1.2 \\
\hline $\mathrm{C}_{16: 0}$ & 9.6 & 10.1 & 7.0 & 12.2 \\
\hline $\mathrm{C}_{17: 0}$ & 6.5 & 6.6 & 10.0 & 20.2 \\
\hline $\mathrm{C}_{18: 0}$ & 1.1 & $\operatorname{tr}$ & $\operatorname{tr}$ & $\operatorname{tr}$ \\
\hline $\mathrm{C}_{15: 1} \omega 8 c$ & $\operatorname{tr}$ & $\operatorname{tr}$ & $\operatorname{tr}$ & 1.1 \\
\hline $\mathrm{C}_{15: 1} \omega 6 c$ & $\operatorname{tr}$ & $\operatorname{tr}$ & $\operatorname{tr}$ & 1.6 \\
\hline $\mathrm{C}_{17: 1} \omega 8 c$ & 6.8 & 7.7 & 8.8 & 11.3 \\
\hline $\mathrm{C}_{17: 1} \omega 6 c$ & 3.4 & 3.9 & 10.9 & 18.9 \\
\hline iso- $\mathrm{C}_{16: 0}$ & 16.7 & 15.8 & 9.3 & - \\
\hline iso- $\mathrm{C}_{18: 0}$ & 5.5 & 4.4 & 1.9 & - \\
\hline iso- $\mathrm{C}_{18: 1} \mathrm{H}$ & 1.3 & 1.3 & $\operatorname{tr}$ & - \\
\hline $\mathrm{C}_{10: 0} 3-\mathrm{OH}$ & 1.0 & $\operatorname{tr}$ & - & - \\
\hline iso- $\mathrm{C}_{14: 0} 3-\mathrm{OH}$ & 1.2 & 1.2 & 1.3 & - \\
\hline 11-Methyl $\mathrm{C}_{18: 1} \omega 7 c$ & 1.2 & $\operatorname{tr}$ & $\operatorname{tr}$ & - \\
\hline \multicolumn{5}{|l|}{ Summed features ${ }^{\star}$} \\
\hline 1 & $\operatorname{tr}$ & $\operatorname{tr}$ & $\operatorname{tr}$ & 1.8 \\
\hline 3 & 10.7 & 14.4 & 11.6 & 18.0 \\
\hline 7 & 1.8 & $\operatorname{tr}$ & $\operatorname{tr}$ & - \\
\hline 8 & 27.4 & 28.1 & 30.1 & 12.0 \\
\hline
\end{tabular}

*Summed features represent two or three fatty acids that cannot be separated by the Microbial Identification System. Summed feature 1 consisted of iso- $\mathrm{C}_{15: 1} \mathrm{H}$ and/or $\mathrm{C}_{13: 0} 3-\mathrm{OH}$; summed feature 3 consisted of $\mathrm{C}_{16: 1} \omega 6 c$ and/or $\mathrm{C}_{16: 1} \omega 7 c$; summed feature 7 consisted of $\mathrm{C}_{19: 1} \omega 7 c$ and/or $\mathrm{C}_{19: 1} \omega 6 c$; summed feature 8 consisted of $\mathrm{C}_{18: 1} \omega 7 c$ and/or $\mathrm{C}_{18: 1} \omega 6 c$. two unidentified phospholipids and two unidentified polar lipids (Supplementary Fig. S1, available in IJSEM Online). The respiratory quinones detected in strains IMCC $4489^{\mathrm{T}}$ and IMCC4451 were ubiquinones, with Q-8 predominating and Q-9 present in minor amounts, as described for the genus Reinekea.

The formation of a robust clade by strains IMCC $4489^{\mathrm{T}}$ and IMCC4451 and the type strains of species of the genus Reinekea and the chemotaxonomic characteristics supported the isolates being assigned to the genus Reinekea. However, the low DNA-DNA relatedness between the isolates and R. blandensis CCUG $52066^{\mathrm{T}}$, the low $16 \mathrm{~S}$ rRNA gene sequence similarity between the isolates and $R$. marinisedimentorum DSM $15388^{\mathrm{T}}$ and several phenotypic characteristics suggested that strains IMCC $4489^{\mathrm{T}}$ and IMCC4451 represent a novel species of the genus Reinekea, for which the name Reinekea aestuarii sp. nov. is proposed.

\section{Description of Reinekea aestuarii sp. nov.}

Reinekea aestuarii (a.es.tu.a'ri.i. L. gen. n. aestuarii of a tidal flat).

Gram-negative, chemoheterotrophic, oxidase- and catalase-positive, non-motile, non-pigmented and facultatively anaerobic. Grows anaerobically but aerobic growth is much better than anaerobic growth. Cells are curved rods (0.4$0.5 \times 1.2-2.5 \mu \mathrm{m})$ that divide by binary fission. After growth on $\mathrm{MA}$ at $25{ }^{\circ} \mathrm{C}$ for 5 days, colonies are $0.2-$ $0.4 \mathrm{~mm}$ in diameter, circular, convex, opaque, smooth and beige. Grows at $15-42{ }^{\circ} \mathrm{C}$ (optimum $25^{\circ} \mathrm{C}$ ), at $\mathrm{pH} 5.0$ 12.0 (optimum $\mathrm{pH} 6.0-8.0$ ) and with $0.5-10.0 \% \mathrm{NaCl}$ (optimum 2.0-5.0\% NaCl). Gelatin, chitin and Tween 80 are hydrolysed, but DNA, starch and casein are not. $\mathrm{H}_{2} \mathrm{~S}$ is not produced. With API 20NE, positive for aesculin hydrolysis but negative for nitrate reduction, indole production, glucose fermentation, arginine dihydrolase, urease and $\beta$-galactosidase. With API ZYM, positive for acid phosphatase, alkaline phosphatase, esterase (C4), esterase lipase (C8), cystine arylamidase, leucine arylamidase, valine arylamidase, trypsin, naphthol-AS-BI-phosphohydrolase and $N$-acetyl- $\beta$-glucosaminidase. With API $50 \mathrm{CH}$, positive for acid production from L-arabinose, arbutin, glycogen and $\mathrm{N}$-acetylglucosamine and variable for cellobiose, glycerol, D-galactose, gentiobiose, lactose, maltose, trehalose, methyl $\alpha$-D-glucopyranoside and potassium-5-ketogluconate. With GN2 MicroPlates, positive for oxidation of cellobiose, $\alpha$-cyclodextrin, glycogen, $N$ acetyl-D-glucosamine, D-fructose, D-galactose, gentiobiose, $\alpha$-D-glucose, lactose, lactulose, maltose, D-mannitol, Dmannose, melibiose, raffinose, D-sorbitol, sucrose, trehalose, turanose, acetic acid, D-galacturonic acid, DL-lactic acid, succinic acid, L-alanine, L-asparagine, L-aspartic acid, L-glutamic acid, glycyl L-glutamic acid, inosine, uridine, thymidine, glycerol, DL- $\alpha$-glycerol phosphate and D-glucose 6-phosphate and variable for oxidation of i-erythritol, Lalaninamide, $\alpha$-ketoglutaric acid, methyl $\beta$-D-glucoside, 
D-glucosaminic acid, D-alanine and $\alpha$-D-glucose 1-phosphate. The major respiratory quinone is Q-8. The polar lipids of the type strain consist of diphosphatidylglycerol, phosphatidylglycerol, phosphatidylethanolamine, phosphatidylserine, two unidentified phospholipids and two unidentified polar lipids. The predominant cellular fatty acids are summed feature $8\left(\mathrm{C}_{18: 1} \omega 7 c\right.$ and/or $\left.\mathrm{C}_{18: 1} \omega 6 c\right)$, iso- $\mathrm{C}_{16: 0}$ and summed feature $3\left(\mathrm{C}_{16: 1} \omega 7 c\right.$ and/or $\mathrm{C}_{16: 1}(\omega 6 c)$. The DNA $\mathrm{G}+\mathrm{C}$ content of the type strain is $51.3 \mathrm{~mol} \%$.

The type strain is IMCC $4489^{\mathrm{T}}\left(=\mathrm{KCTC} 22813^{\mathrm{T}}=\mathrm{KCCM}\right.$ $\left.42938^{\mathrm{T}}=\mathrm{NBRC} 106079^{\mathrm{T}}\right)$, isolated from a tidal flat of the Yellow Sea, Korea.

\section{Acknowledgements}

This study was supported by the 21C Frontier Program of Microbial Genomics and Applications, by the Korea Research Foundation Grant funded by MEST (KRF-2007-314-C00265) and by a grant from the Gyeonggi Sea Grant Program funded by the MLTM of the Korean government.

\section{References}

Cho, J. C. \& Giovannoni, S. J. (2004). Cultivation and growth characteristics of a diverse group of oligotrophic marine Gammaproteobacteria. Appl Environ Microbiol 70, 432-440.

Choo, Y.-J., Lee, K., Song, J. \& Cho, J.-C. (2007). Puniceicoccus vermicola gen. nov., sp. nov., a novel marine bacterium, and description of Puniceicoccaceae fam. nov., Puniceicoccales ord. nov., Opitutaceae fam. nov., Opitutales ord. nov. and Opitutae classis nov. in the phylum 'Verrucomicrobia'. Int J Syst Evol Microbiol 57, 532-537.

Chun, J., Lee, J.-H., Jung, Y., Kim, M., Kim, S., Kim, B. K. \& Lim, Y.-W. (2007). EzTaxon: a web-based tool for the identification of prokaryotes based on $16 \mathrm{~S}$ ribosomal RNA gene sequences. Int J Syst Evol Microbiol 57, 2259-2261.

Collins, M. (1985). Analysis of isoprenoid quinones. Methods Microbiol 18, 329-366.

Ezaki, T., Hashimoto, Y. \& Yabuuchi, E. (1989). Fluorometric deoxyribonucleic acid-deoxyribonucleic acid hybridization in microdilution wells as an alternative to membrane filter hybridization in which radioisotopes are used to determine genetic relatedness among bacterial strains. Int J Syst Bacteriol 39, 224-229.

Felsenstein, J. (1981). Evolutionary trees from DNA sequences: a maximum likelihood approach. J Mol Evol 17, 368-376.
Fitch, W. M. (1971). Toward defining the course of evolution: minimum change for a specific tree topology. Syst Zool 20, 406-416.

Garrity, G. M., Bell, J. A. \& Lilburn, T. (2005). Order VIII. Oceanospirillales ord. nov. In Bergey's Manual of Systematic Bacteriology, 2nd edn, vol. 2B, p. 270. Edited by D. J. Brenner, N. R. Krieg, J. T. Staley \& G. M. Garrity. New York: Springer.

Jukes, T. H. \& Cantor, C. R. (1969). Evolution of protein molecules. In Mammalian Protein Metabolism, vol. 3, pp. 21-32. Edited by H. N. Munro. New York: Academic Press.

Ludwig, W., Strunk, O., Westram, R., Richter, L., Meier, H., Yadhukumar, Buchner, A., Lai, T., Steppi, S \& other authors (2004). ARB: a software environment for sequence data. Nucleic Acids Res 32, 1363-1371.

Mesbah, M., Premachandran, U. \& Whitman, W. B. (1989). Precise measurement of the $\mathrm{G}+\mathrm{C}$ content of deoxyribonucleic acid by highperformance liquid chromatography. Int J Syst Bacteriol 39, 159-167.

Minnikin, D. E., O'Donnell, A. G., Goodfellow, M., Alderson, G., Athalye, M., Schaal, A. \& Parlett, J. H. (1984). An integrated procedure for the extraction of bacterial isoprenoid quinones and polar lipids. J Microbiol Methods 2, 233-241.

Pinhassi, J., Pujalte, M. J., Macián, M. C., Lekunberri, I., González, J. M., Pedrós-Alió, C. \& Arahal, D. R. (2007). Reinekea blandensis sp. nov., a marine, genome-sequenced gammaproteobacterium. Int J Syst Evol Microbiol 57, 2370-2375.

Romanenko, L. A., Schumann, P., Rohde, M., Mikhailov, V. V. \& Stackebrandt, E. (2004). Reinekea marinisedimentorum gen. nov., sp. nov., a novel gammaproteobacterium from marine coastal sediments. Int J Syst Evol Microbiol 54, 669-673.

Saitou, N. \& Nei, M. (1987). The neighbor-joining method: a new method for reconstructing phylogenetic trees. Mol Biol Evol 4, 406425.

Smibert, R. M. \& Krieg, N. R. (1994). Phenotypic characterization. In Methods for General and Molecular Bacteriology, pp. 607-654. Edited by P. Gerhardt, R. G. E. Murray, W. A. Wood \& N. R. Krieg. Washington, DC: American Society for Microbiology.

Stackebrandt, E. \& Ebers, J. (2006). Taxonomic parameters revisited: tarnished gold standards. Microbiol Today 33, 152-155.

Stackebrandt, E. \& Goebel, B. M. (1994). Taxonomic note: a place for DNA-DNA reassociation and $16 \mathrm{~S}$ rRNA sequence analysis in the present species definition in bacteriology. Int J Syst Bacteriol 44, 846849.

Wayne, L. G., Brenner, D. J., Colwell, R. R., Grimont, P. A. D., Kandler, O., Krichevsky, M. I., Moore, L. H., Moore, W. E. C., Murray, R. G. E. \& other authors (1987). International Committee on Systematic Bacteriology. Report of the ad hoc committee on reconciliation of approaches to bacterial systematics. Int J Syst Bacteriol 37, 463-464. 